Institution at the jubilee meetings of the American Society of Mechanical Engineers. In 1934 he delivered the Thomas Lowe Gray Lecture of the Institution, taking as his subject "A Survey of Ships and Engines".

Having guided the fortunes of The Engineer during two world wars and the great depression of the ' $30 \mathrm{~s}$, Pendred resigned his editorship in 1946 and was succeeded by his second son, Benjamin Pendred, who had joined the staff in 1931. During the First World War, Pendred was editor of The Ministry of Munitions Journal, and for this and other services to engineering, in 1934 was created C.B.E. The Institution of Mechanical Engineers also made him an honorary member.

Always interested in the history of engineering, Loughnan Pendred played an important part in the inauguration in 1920 of the Newcomen Society, and it was at a dinner given by him to some of its founders, at the Savage Club, then housed in the Adelphi, that the name of Thomas Newcomen was adopted for the new Society. Pendred was one of the original members of council and during 1922-24 and 1928-30 served as president; on October 26, 1923, delivering a stimulating address on "The Value of Technological History". Among his other contributions to the Transactions of the Society was a scholarly address given in Dartford Parish Church on the occasion of the commemoration on April 23, 1933, of the centenary of Richard Trevithick. Other societies with which he was connected include the Iron and Steel Institute, the Junior Institution of Engineers, of which he was an honorary member, and the Institution of Engineers-in-Charge, of which he served as president. In an appreciation of Pendred when he retired, Mr. G. E. Chadwyck-Healey, a grandson of Edward Healey, wrote : "I count myself fortunate in having had so kindly, wise and steadfast a friend". There are others who will feel the same. EdGar C. SMITH

\section{Mr. A. B. Broughton-Edge, M.B.E.}

Mr. Arthur Broughton Broughton-Edge, who died on October 8 after an illness which dated from 1940 , was a man of very wide interests, demonstrated by his membership of the Institution of Mining and Metallurgy, the Chemical Society, the Mineralogical Society, the Geological Society and the Geologists' Association. His main concern, however, was in geology and the use of geophysical methods in the search for minerals, and in this latter branch he was one of the early pioneers. Born on March 16, 1895, and educated at Bradfield College, Berks, he joined the University and Public Schools Corps at the outbreak of the First World War. Later, commissioned in the Royal Artillery, he saw active service in France, Salonika, etc., with an Indian Mountain Battery. He was invalided to England after an injury in Greece and spent the last part of the War investigating poisonous gases and, as a result, himself suffered from their effects. This phase of his career, for which he was made M.B.F., may well reflect his early interest in chemistry.

In 1918, however, Mr. Broughton-Edge entered the Royal School of Mines and studied geology, in particular the geology of mineral deposits, under Prof. C. G. Cullis, obtaining an A.R.S.M. in 1921 and a B.Sc. in 1922. As a student he visited Cyprus and was a joint author with Prof. Cullis of an authoritative work on "The Cupriferous Deposits of Cyprus", ultimately published in 1926. Although he studied numerous types of mineral deposits in many parts of the world and was active in the examination of old mineral fields of Great Britain, he will be mainly remembered for his early investigations into the use of geophysical prospecting methods in the search for minerals. In $\mathbf{1 9 2 5}$ he was experimenting in Africa with electrical methods, and this valuable experience naturally led in 1928 to his appointment as director of the Imperial Geophysical Experimental Survey in Australia. The report of this survey, which was jointly financed by the Empire Marketing Board and the Australian Government, did much to remove the mystery which surrounded the procedures at that time and placed them on a sound scientific basis.

In 1935 he married Muriel Docea Pullman, who nursed him devotedly during his illness until her untimely death in 1947. Mr. Edge's fortitude during this period was outstanding and, despite his obvious handicaps, he investigated the uses of the microscope for special mineralogical problems, the results of which will be published posthumously.

\section{Mr. Robert Donaldson}

THE sudden death on November 5 of Robert Donaldson has deprived physical optics of one of its well-known workers. Born in 1904, he obtained a first in his M.A. in the University of Edinburgh and, after two years as demonstrator in the Department of Natural Philosophy there, went to the National Physical Laboratory in 1928. He was, in those days, as much a mathematician as a physicist and was specially fitted for the post of assistant to John Guild, then conducting his classical researches in the measurement of colour. This early work set the pattern for all that followed for, except during the war years, when he participated in the general work of the Light Division of the Laboratory, Donaldson was primarily occupied with the field of colorimetry, heterochromatic photometry and spectrophotometry.

In 1933 he became head of the colorimetry section of the Division and made outstanding contributions to the subject by the design of instruments and the development of now techniques; by investigating problems arising from the commercial introduction of new illuminants and colorants, for example, fluorescent lamps and paints; by providing the experimental data, apparatus and methods for new applications of colour in the medical field, such as colorimetric hæmoglobinometry and spectrophotometric tests for vitamins ; and by the improvement of the standardizing procedures called for by the many specifications now governing the supply of lights and filters for rail and road signalling, marine and aerial navigation, aerodrome lighting, etc. Donaldson had a special aptitude for getting to the roots of a research problem, and this is well shown by a few examples of some of the instruments which bear his name.

The first trichromatic colorimeter designed at the National Physical Laboratory was intended primarily for the researches in the Laboratory which led to the establishment of the present international system of colour standardization. It required a supply of direct current and so proved inconvenient for use in industrial laboratories, many of which had only a public supply of alternating current available. Donaldson designed a colorimeter in which the blending of the trichromatic stimuli is effected by an integrating sphere, and which can be used with either A.c. or D.c. supply. This instrument is now the most widely 